\title{
Efficacy of Bio-Intensive Integrated Pest Management against Brinjal Shoot and Fruit Borer Leucinodes Orbonalis Guenee (Lepidoptera : Pyralidae)
}

\author{
Mou Biswas*, Ipsita Mishra and B. K. Mishra \\ Department of Entomology, College of Agriculture, Odisha, \\ University of Agriculture and Technology, Bhubaneswar- 751003, India \\ *Corresponding author
}

Keywords

Brinjal; Biointensive Integrated Pest Management; Leucinodes orbonalis

Article Info

Accepted: 08 January 2020 Available Online: 10 February 2020

\section{A B S T R A C T}

Field experiments were carried out in the farmer's fields in five different villages during 2013 and 2014 to evaluate two bio-intensive integrated pest management (BIPM) modules against Leucinodes orbonalis on brinjal which were compared with one insecticidal check along with farmers' practice to ascertain their effectiveness. The study evidenced the superiority of BIPM in all aspects viz., lesser shoot infestation (1.6-2.5 and 3-5.4\%), lesser fruit damage(3.2-5.0 and 35.4\%)and higher yield(261.2-299.1 and 254.5-276.7 Q/ha). Besides, the treatment BIPM proved its efficacy over farmer's practice and untreated control especially with high percent increase of yield and percent reduction of shoot and fruit infestation. Apart from this the benefit cost ratio (BCR) ranked in the order of superiority as BIPM modules with (1: 8.19) and (1:8.55)which was greater than the farmer practice(1:2.10 and 1:2.75). The insecticide check had 282.7-315.4 and 276.9-302.8 quintals of yield,1.2-2.2, 1.9-2.8 and 2.9-4.5,2.8-4.9 percent reduction of shoot and fruit infestation which were at par with the BIPM modules. The present study indicates that BIPM is equally effective as that of insecticide application as evidenced from the insecticidal application and the yield was also equal to that of the insecticidal application.

\section{Introduction}

Vegetable cultivation is a significant part of the national agricultural economy, especially in the developing world (Srivastav, 2012). The brinjal (Solanum melongena) is the native to Indian Subcontinent (Tsao and Lo 2006; Doijode 2001) and belongs to the family
Solanaceae. It is called brinjal in India, and Aubergine in Europe.It contributes $9 \%$ of the total vegetable production of India (Sidhu and Dhatt, 2007). India has second rank in both area and production and $8^{\text {th }}$ in productivity in all brinjal growing country. A survey of vegetable pests conducted by AVRDC-the World Vegetable Center indicated that Brinjal 
Shoot and Fruit Borer( BSFB) is the most destructive pest in most major eggplant producing countries of South Asia. In order to get maximum yield from the cultivation, farmers rely exclusively on the application of pesticides to control BSFB and to produce blemish-free eggplant fruit. Besides, indiscriminate use of pesticides in brinjal resulted in development of resurgence of secondary pests such as whitefly, mites and thrips (Krishnakumar and Krishnamoorthy, 2001), kill the natural enemies of $L$. orbonalis, which were giving satisfactory control of the pest before the use of insecticides became widespread (Talekar 2002). Considering these drawbacks, the present study was undertaken to find out the efficacy of Bio-intensive Integrated Pest Management against $L$. orbonalis.

\section{Materials and Methods}

The field experiments were carried out to evaluate bio-intensive integrated pest management (BIPM) against $L$. orbonalis on brinjal in the farmer's fields during 2013 and 2014 to ascertain the effectiveness against insecticidal control and yield of marketable brinjal fruit. Experiments were conducted in a Complete Block Design (CBD) with the spacing of $60 \times 60 \mathrm{~cm}$ for brinjal. Two BIPM modules were evaluated in larger plot. The treatments were applied in an area of one acre each during both the years and were tested in five villages. Ten spots of $5 \times 5 \mathrm{~m}$ were selected from each field for taking observations on the incidence of shoot and fruit borer and were considered as replications, in a CBD design (Gomez and Gomez, 1984). Data obtained were statistically analyzed and economics was calculated. To avoid spray contamination $5 \mathrm{~m}$ distance was maintained between treatment plots. All agronomic practices except management practices against $L$. orbonalis were followed regularly.

\section{BIPM module-I}

In BIPM module treated plots (Table 1), the activity of adults $L$. orbonalis was monitored by the installation of sex pheromone traps. The traps were installed at the plot once after the proper notification of adult moths at the field just after 15 days of transplanting and at the rate of 25 traps/ha. The sex pheromone, Lucin-lure and Wota-T traps were obtained at Pest Control India (Pvt) Ltd. The pheromone lure was replaced by 21 days interval (Lalitha Kumari and Reddy, 1992; Patil and Mamadapur, 1996; Loganathan et al., 1999) until the end of cropping season. According to the availability of adult moths in the field, a combination of management practices was applied properly on time to reduce the infestation of L.orbonalis. Soon after the notification of adult moths, the egg parasitoids Trichogramma chilonis were released at weakly interval at the rate of $50,000 \mathrm{eggs} / \mathrm{ha} /$ weak after $20 \mathrm{DAP}$ (total of 15 releases till harvest). Bt (Dipel) was sprayed twice@2 ml/l at 10 days intervals at peak flowering stsage.

\section{BIPM module-II}

In addition to the practices followed in BIPM module-I, application of $100 \mathrm{~kg}$ neem cake at final ploughing and Weekly Removal of wilted twigs are followed.

\section{Insecticidal check}

Alternate spray of Flubendiamide $80 \mathrm{~g}$ a i /ha and Spinosad $90 \mathrm{ml}$ a i /ha at 15 fdays interval were followed.

\section{Farmer's practice}

In Farmer's Practice module treated plots, the management practices against L.orbonalis generally adapted by farmers were undertaken. The treatment details in each module are listed in Table 1. 
Table.1 Validation of BIPM module in Kharif 2013 and 2014

\begin{tabular}{|c|c|c|c|c|c|c|}
\hline \multicolumn{3}{|c|}{2013} & \multicolumn{4}{|c|}{2014} \\
\hline Treatments & $\begin{array}{l}\text { Shoot } \\
\text { damage }(\%)\end{array}$ & $\begin{array}{l}\text { Fruit } \\
\text { damage(\%) }\end{array}$ & Yield(q/ha) & $\begin{array}{l}\text { Shoot } \\
\text { damage }(\%)\end{array}$ & $\begin{array}{l}\text { Fruit } \\
\text { damage(\%) }\end{array}$ & Yield(q/ha) \\
\hline \multicolumn{7}{|c|}{$\begin{array}{l}\text { Location } \\
\text { Kakharubasta }\end{array}$} \\
\hline BIPM module I & $4.6(2.14)$ & $10.5(3.24)$ & 250.8 & $4.9(2.21)$ & $10.8(3.29)$ & 216.8 \\
\hline BIPM module II & $2.3(1.51)$ & $4.8(2.19)$ & 289.8 & $2.4(1.54)$ & $4.3(2.07)$ & 254.5 \\
\hline Insecticidal check & $2.1(1.45)$ & $4.5(2.12)$ & 300.3 & $2.2(1.48)$ & $4.9(2.02)$ & 276.9 \\
\hline Farmer's practice & $8.1(2.85)$ & $16.2(1.02)$ & 180.4 & $9.3(3.05)$ & $17.4(4.17)$ & 187.8 \\
\hline $\mathrm{SE}(\mathrm{m}) \pm$ & $(0.09)$ & $(0.13)$ & & $(0.09)$ & $(0.23)$ & \\
\hline $\mathrm{CD}(\mathrm{P}=0.05)$ & $(0.30)$ & $(0.40)$ & (16.56) & $(0.30)$ & $(0.70)$ & $(22.38)$ \\
\hline \multicolumn{7}{|l|}{ Location : Kulei } \\
\hline BIPM module I & $3.1(1.76)$ & $6.3(2.5)$ & 245.8 & $3.7(1.92)$ & $6.6(2.57)$ & 218.5 \\
\hline BIPM module II & $2.0(1.41)$ & $3.2(1.78)$ & 296.3 & $2.9(1.70)$ & $3.0(1.73)$ & 257.9 \\
\hline Insecticidal check & $1.8(1.34)$ & $2.9(1.70)$ & 310.4 & $2.5(1.58)$ & $2.8(1.67)$ & 279.1 \\
\hline Farmer's practice & $5.9(2.43)$ & $1.78(4.22)$ & 172.6 & $11.6(3.40)$ & $21.2(4.60)$ & 168.0 \\
\hline $\mathrm{SE}(\mathrm{m}) \pm$ & $(0.09)$ & $(0.13)$ & & & $(0.09)$ & \\
\hline $\mathrm{CD}(\mathrm{P}=0.05)$ & $(0.30)$ & $(0.40)$ & $(23.17)$ & $(0.50)$ & $(0.30)$ & $(22.44)$ \\
\hline \multicolumn{7}{|c|}{$\begin{array}{l}\text { Location } \\
\text { Bangursingh }\end{array}$} \\
\hline BIPM module I & $2.3(1.52)$ & $7.8(2.80)$ & 249.6 & $3.6(1.89)$ & $8.8(2.96)$ & 228.0 \\
\hline BIPM module II & $1.6(1.26)$ & $4.4(2.10)$ & 299.1 & $2.1(1.44)$ & $5.4(2.32)$ & 259.2 \\
\hline Insecticidal check & $1.3(1.14)$ & $3.6(1.90)$ & 315.4 & $1.9(1.38)$ & $4.1(2.25)$ & 288.6 \\
\hline Farmer's practice & $7.4(2.72)$ & $14.9(3.86)$ & 171.3 & $8.1(2.85)$ & $16.3(4.03)$ & 180.7 \\
\hline $\mathrm{SE}(\mathrm{m}) \pm$ & $(0.13)$ & $(0.32)$ & & $(0.13)$ & $(0.45)$ & \\
\hline $\mathrm{CD}(\mathrm{P}=0.05)$ & $(0.40)$ & $(1.00)$ & (20.74) & $(0.40)$ & $(1.38)$ & $(29.44)$ \\
\hline \multicolumn{7}{|c|}{ Location : Saradhapur } \\
\hline BIPM module I & $4.8(2.19)$ & $9.3(3.05)$ & 238.4 & $4.6(2.14)$ & $9.7(3.11)$ & 144.9 \\
\hline BIPM module II & $2.5(1.58)$ & $5.0(2.23)$ & 268.2 & $2.4(1.54)$ & $4.2(2.05)$ & 276.7 \\
\hline Insecticidal check & $2.2(1.48)$ & $4.1(2.02)$ & 295.3 & $2.1(1.45)$ & $3.9(1.97)$ & 302.8 \\
\hline Farmer's practice & $10.3(3.21)$ & $15.5(3.94)$ & 169.3 & $9.7(3.11)$ & $14.7(2.03)$ & 161.3 \\
\hline $\mathrm{SE}(\mathrm{m}) \pm$ & $(0.13)$ & $(0.32)$ & & $(0.13)$ & $(0.13)$ & \\
\hline $\mathrm{CD}(\mathrm{P}=0.05)$ & $(0.40)$ & $(1.00)$ & $(27.10)$ & $(0.40)$ & $(0.40)$ & $(26.31)$ \\
\hline \multicolumn{7}{|c|}{$\begin{array}{l}\text { Location : } \\
\text { Hatakaranda }\end{array}$} \\
\hline BIPM module I & $3.6(1.90)$ & $8.7(2.95)$ & 236.9 & $5.1(2.25)$ & $9.6(3.09$ & 216.9 \\
\hline BIPM module II & $1.9(1.37)$ & $4.3(2.07)$ & 261.2 & $3.0(1.73$ & $4.0(2.0)$ & 255.4 \\
\hline Insecticidal check & $1.2(1.1)$ & $3.1(1.76)$ & 282.7 & $2.8(1.67)$ & $3.8(1.95)$ & 287.5 \\
\hline Farmer's practice & $8.8(2.90)$ & $14.2(3.77)$ & 189.6 & $11.1(3.24)$ & $15.6(3.94)$ & 152.6 \\
\hline $\mathrm{SE}(\mathrm{m}) \pm$ & $(0.32)$ & $(0.42)$ & & $(0.09)$ & $(0.09)$ & \\
\hline $\mathrm{CD}(\mathrm{P}=0.05)$ & $(1.00)$ & $(1.30)$ & $(21.50)$ & $(0.30)$ & $(0.30)$ & (32.10) \\
\hline
\end{tabular}

Figures in parentheses are $\sqrt{ }$ values.

Insecticidal application:- Alternate spray of Flubendiamide $80 \mathrm{~g}$ a i /ha and Spinosad $90 \mathrm{ml}$ a i /ha at 15 fdays interval. 
The infested shoots of brinjal by L. orbonalis, were counted from 10 randomly selected plants at fifteen days interval since 15 days after transplanting whereas infested fruit by $L$. orbonalis were recorded from 50 days after transplanting at ten days interval. The per cent shoot and fruit infestation was calculated by counting healthy and infested shoots and fruits at each observation. Economic analysis of BIPM module involving yield and the benefit cost ratio (BCR) were estimated.

\section{Results and Discussion}

Two bio-intensive pest management schedules and one insecticidal check(Module III) along with farmers' practice (Module IV) as described in (Table 1) were evaluated against the shoot and fruit borer in 5 villages. During 2013 shoot damage in Module-I varied between 2.3 to $4.8 \%$ in different villages whereas it was 1.6 to $2.5 \%$ in Module II, 1.2 to $2.2 \%$ in Module III and 5.9 to $10.3 \%$ in different villages. Similarly fruit damage ranged between 6.3 to $10.5 \%, 3.2$ to $5.0 \%, 2.9$ to $4.5 \%$ and 14.2 to $17.8 \%$ in module I,II,III and IV respectively. Accordingly the yield was 236.9 to 250.8 , 261.2 to $299.1,285.7$ to 315.4 and 169.3 to $189.6 \mathrm{q} / \mathrm{ha}$ respectively.

During 2014, the shoot infestation varied between 3.6 to $5.1 \%, 3.0$ to $5.4 \%, 2.8$ to $4.9 \%$ and 14.7 to $21.2 \%$ respectively in all the four modules. The yield was in accordance with the fruit infestation and ranged between 144.9 to $276.7,254.5$ to 276.7 and 276.9 to $302.8 \mathrm{q} / \mathrm{ha}$ in module I,II and III respectively. Where as in the control plots ( module IV) it ranged between 152.6 to $187.8 \mathrm{q} / \mathrm{ha}$.

Module II and III were found equally effective in the management of the shoot and fruit borer as reflected from the cost: benefit ratio. Module $\mathrm{I}$ has cost benefit ratio of 1 : 4.88 in 2013 whereas, Module II and III have 1: 9.11 and 1: 8.19 Cost : Benefit ratio respectively. Similarly in 2014, Module I C: $\mathrm{B}$ ratio is $1: 5.12$, whereas in Module II and Module III C:B ratio found 1: 9.62 and 1: 8.55 respectively.

Table.2 Economics of different BIPM modules for L.orbonalis management

\begin{tabular}{|c|c|c|c|c|c|c|c|}
\hline \multicolumn{8}{|c|}{2013} \\
\hline $\begin{array}{l}\text { Sl. } \\
\text { No. }\end{array}$ & Treatment & $\begin{array}{l}\text { Ave. } \\
\text { yield } \\
\text { (q/ha) }\end{array}$ & $\begin{array}{l}\text { Increase } \\
\text { over } \\
\text { control(q) }\end{array}$ & $\begin{array}{l}\text { Yield } \\
\text { value }\end{array}$ & $\begin{array}{l}\text { Cost of } \\
\text { treatment(Rs.) }\end{array}$ & $\begin{array}{l}\text { Net profit } \\
\text { (Rs.) }\end{array}$ & $\begin{array}{l}\text { Cost } \\
\text { benefit } \\
\text { Ratio(C:B) }\end{array}$ \\
\hline 1 & Module I & 244.30 & 67.66 & 244300.00 & 41547.61 & 202752.39 & $1: 4.88$ \\
\hline 2 & Module II & 282.92 & 106.28 & 282920.00 & 30785.63 & 252134.37 & 1:8.19 \\
\hline 3 & $\begin{array}{l}\text { Insecticidal } \\
\text { check }\end{array}$ & 300.82 & 124.18 & 300820.00 & 29754.69 & 271065.31 & $1: 9.11$ \\
\hline 4 & $\begin{array}{l}\text { Farmer's } \\
\text { practice }\end{array}$ & 176.64 & & 176640.00 & 45487.09 & 95522.91 & $1: 2.10$ \\
\hline \multicolumn{8}{|c|}{2014} \\
\hline 1 & Module I & 205.02 & 34.94 & 205020.00 & 33500.00 & 171520.00 & $1: 5.12$ \\
\hline 2 & Module II & 260.74 & 90.66 & 260740.00 & 27302.61 & 233437.39 & $1: 8.55$ \\
\hline 3 & $\begin{array}{l}\text { Insecticidal } \\
\text { check }\end{array}$ & 286.98 & 116.90 & 286980.00 & 26785.26 & 311244.74 & $1: 9.62$ \\
\hline 4 & $\begin{array}{l}\text { Farmer's } \\
\text { practice }\end{array}$ & 170.08 & & 170080.00 & 45354.66 & 124725.34 & $1: 2.75$ \\
\hline
\end{tabular}


Bio-intensive IPM mostly focuses on the use of pest control components except insecticides. During the two years two different modules were evaluated in five villages. The first module where Trichogramma chilonis egg parasitoid, BT and pheromone traps were used to get substantial control of the shoot and fruit borer.

It was observed that the BIPM module consisting of Trichogramma egg parasitoids, pheromone trap and Bacillus thuringiensis (Module I) could substantially reduced the shoot and fruit borer incidence over farmers practice (Module IV). But when substantiated with neem cake application, neem pesticide spraying and removal of wilted shoots (Module II), the incidence of the borer pest was substantially reduced and the control was at par with insecticidal control (Module III). The incidence of shoot and fruit borer was at par in the module II and III.

Whereas, it was superior to module I. But module I was superior to module IV (farmers' practice). Farmer's usually apply pesticides on their own and do not report to scientific recommendations. But application of recommended pesticides in proper dose and intervals can fetch them good dividends as shown by module III. BIPM is also equally effective as that of scientific insecticide application as evidenced from the insecticidal application and the yield was also equal to that of the insecticidal application.

But there will be no environmental pollution in adopting module III as no insecticide was applied in this module. Similar observations relating to module I and II agreed with the work done by Chatterjee.H(2009) and Dutta et.al.,(2011). Our observation on BIPM module agrees with observations of Pokharkar and Tirmare (2013), Niranjana and Sridhar (2019).
The Bio-Intensive Pest Management utilised the components like use of egg parasitoid $T$ chilonis, use of the bacterial bio-pesticide, Bacillus thuringiensis and use of pheromone trap with Lucinlure in BIPM module-I whereas it was supplemented with use of neemcake and removal of wilted twigs in Module-II. The module-III comprised of only insecticidal application comprising of alternate spray of Flubendiamide and Rynaxypyr and Spinosad at 15 days interval. Altogether 6 sprays were given. The moduleIV comprised of farmers practice where the farmers used the conventional plant protection taken up in that locality, primarily insecticides from local market. BIPM module II and insecticidal check were at par in their efficiency regarding management of the shoot and fruit borer, emphasizing that without insecticide the pest can be effectively managed with no compromise on the yield of brinjal. Even in BIPM module-I, the pest reduction and yield were significantly superior to that of the control.

\section{References}

Chatterjee,H.(2009). Pheromones for the management of brinjal fruit and shoot borer, Leucinodes orbonalis Guenee, Karnataka J. Agric. Sci., 22(3-Spl. Issue ) : (594-596).

Doijode, S. D. (2001). Seed storage of horticultural crops (157). Haworth Press: ISBN 1-56022-901-2.

Dutta P , Singha AK, Das P and Kalita S. 2011. Management of brinjal fruit and shoot borer, Leucinodes orbonalis (Guenée) in agro-ecological condition of West Tripura, Scholarly Journal of Agricultural Science, 1(2): 16-19.

Gomez KA, Gomez AA. Statistical Procedures for Agricultural Research, John Wiley and Sons, New York, 1984

Krishnakumar, N. K. and Krishnamoorthy,P. N. (2001). Integrated Pest Management 
of insects damaging solanaceous vegetables. In: Integrated Pest Management in Horticultural Ecosystems. Reddy, P., A. Verghese and N. K. Krishnakumar (Eds.). Capital publishing company. New Delhi. 35 45.

Lalitha Kumari, V. L. and D. D. R. Reddy. (1992). Evaluation of pheromone trap designs for trapping Spodoptera litura and Helicoverpa armigera and their reproductive behavior. Indian Journal of Plant Protection. 20: 18-23.

Loganathan, M., Sasikumar, M. and Uthamaswamy, S. (1999). Assessment of duration of pheromone dispersion for monitoring Helicoverpa armigera (H.) on cotton. J. Ent. Res., 23(1): 61-64.

Niranjana, R. F., Devi, M., Shanika, W. and Philip Sridhar, R. (2015). Potential Use of Egg Parasitoids, Trichogramma pretiosum Riley and Trichogramma chilonis Ishii against Brinjal Shoot and Fruit Borer, Leucinodes orbonalis Guenée. Tropical Agricultural Research, 27 (1): 88- 94.

Patil, B. V. and Mamadapur. B. B. (1996). Performance of some sex pheromone traps and lures of Helicoverpa armigera (H.). Indian Journal of Plant Protection. 24(1\&2): 128-129.
Pokharkar DS and Tirmare DS. 2013. Biointensive pest management of shoot and fruit borer, Leucinodes orbonalis in brinjal, Journal of Insect Science, 26(2): 215-219.

Sidhu, A. S. and Dhatt, A. S. (2007). Current status of Brinjal research in India. In: Proc.1stIC on Indig. Veg. and Legumes. (Eds.) M. L. Chadha et al., Acta Hort., 752.

Srivatav D. Gene targeting based genetic Transformation In brinjal (Solanum melongena L.) $\mathrm{Ph}$. D. Thesis Department of Biotechnology, University School of Biotechnology, Guru Gobind Singh Indraprastha University Sector 16c, dwarka, Delhi, 2012.

Talekar, N. S. (2002). Controlling eggplant shoot and fruit borer: A simple, safe and economical approach. International Cooperators' Guide, Publication No. 02- 534, Shanhua, Taiwan: Asian Vegetable Research and Development, Center.

Tsao, and Lo. (2006). In "Vegetables: Types and Biology". Handbook of Food Science, Technology, and Engineering by Yiu H. Hui.CRC Press. ISBN 157444-551- 0. Zoological Researches, 19 (1): $42-45$.

\section{How to cite this article:}

Mou Biswas, Ipsita Mishra and Mishra. B. K. 2020. Efficacy of Bio-Intensive Integrated Pest Management Against Brinjal Shoot and Fruit Borer Leucinodes Orbonalis Guenee (Lepidoptera : Pyralidae). Int.J.Curr.Microbiol.App.Sci. 9(02): 1442-1447. doi: https://doi.org/10.20546/ijcmas.2020.902.167 